\title{
PENGARUH LINGKUNGAN KERJA DAN KEPEMIMPINAN TERHADAP KINERJA PEGAWAI PADA DINAS PERDAGANGAN DAN PERINDUSTRIAN KABUPATEN MUSI BANYUASIN
}

\author{
Oleh : \\ Yeni Marsih \\ (marsihyeni@gmail.com) \\ Sekolah Tinggi Ilmu Ekonomi Rahmaniyah Sekayu
}

\begin{abstract}
ABSTRAK
Tujuan penelitian ini adalah untuk mengetahui untuk mengetahui pengaruh lingkungan kerja dan kepemimpinan terhadap kinerja pegawai pada Dinas Perdagangan Dan Perindustrian Kabupaten Musi Banyuasin. Metode penelitian yang digunakan adalah metode deskriptif kuantitatif. Teknik pengumpulan data yang digunakan adalah penelitian kuesioner, observasi dan studi dokumentasi. Analisis data dilakukan menggunakan uji validitas, uji reliabilitas, uji asumsi klasik, regresi linier berganda, koefisien determinan dan uji hipotesis (uji t) dan uji F.

Hasil pengujian hipotesis ujit $t\left(\mathrm{H}_{1}\right)$ telah membuktikan terdapat pengaruh antara kepemimpinan terhadap kinerja pegawai. Melalui hasil perhitungan yang telah dilakukan diperoleh nilai $t_{\text {hitung }}$ sebesar 2,379. Hasil pengujian hipotesis (uji t) Lingkungan Kerja menunjukkan nilai $t_{\text {hitung }}$ $>\mathrm{t}$ tabel $(2,379>1,989)$, maka Ho ditolak, artinya secara parsial ada pengaruh signifikan antara Lingkungan Kerja terhadap kinerja pegawai. Jadi dari kasus ini dapat disimpulkan bahwa secara parsial Lingkungan Kerja berpengaruh terhadap kinerja pegawai pada Dinas Perdagangan dan Perindustrian Kabupaten Musi Banyuasin dan Hasil pengujian hipotesis $\left(\mathrm{H}_{2}\right)$ telah membuktikan terdapat pengaruh antara kepemimpinan terhadap kinerja pegawai. Melalui hasil perhitungan yang telah dilakukan didapat nilai $\mathrm{t}_{\text {hitung }}$ sebesar 2,388. Hasil nilai $\mathrm{t}_{\text {hitung }}>\mathrm{t}_{\text {tabel }}(2,388>1,989)$, maka $\mathrm{H}_{0}$ ditolak, artinya secara parsial ada pengaruh signifikan antara kepemimpinan dan kinerja pegawai. Jadi dari kasus ini dapat disimpulkan bahwa secara parsial kepemimpinan ada pengaruh terhadap kinerja pegawai pada Dinas Perdagangan dan Perindustrian Kabupaten Musi Banyuasin

Berdasarkan hasil penelitian dari pengujian pengaruh variabel bebas secara simultan terhadap variabel terikatnya dilakukan dengan menggunakan uji F. Hasil perhitungan statistik menunjukkan nilai $\mathrm{F}_{\text {hitung }}=6,036$, maka diperoleh nilai $\mathrm{F}_{\text {hitung }} 6,036>$ dari $\mathrm{F}_{\text {tabel }} 3,11 . \mathrm{Maka}_{\mathrm{o}}$ ditolak dan menerima $\mathrm{H}_{\mathrm{a}}$. Hal ini berarti bahwa hipotesis yang menyatakan bahwa secara simultan variable ada pengaruh lingkungan kerja dan kepemimpinan terhadap kinerja pegawai pada Dinas Perdagangan Dan Perindustrian Kabupaten Musi Banyuasin.
\end{abstract}

\section{Kata Kunci : Lingkungan Kerja, Kepemimpinan, Kinerja Pegawai}

\section{Latar Belakang}

Menurut Bangun (2012: 231), kinerja adalah hasil pekerjaan yang dicapai seseorang berdasarkan persyaratan-persyaratan pekerjaan. Suatu pekerjaan mempunyai persyaratan tertentu untuk dapat dilakukan dalam mencapai tujuan yang disebut juga sebagai standar pekerjaan. Berkaitan dengan hal tersebut salah satu yang menjadi penyebab menurunnya kinerja pegawai adalah lingkungan kerja yang menjadi salah satu faktor yang mempengaruhi kinerja pegawai, lingkungan kerja baik kondisi fisik maupun non-fisik (psikis) yang kondusif serta lingkungan secara langsung dan tidak langsung dapat mempengaruhi pegawai baik pada dirinya dan pekerjaannya saat bekerja.

Menurut Sedarmayati (2011: 28), lingkungan kerja adalah keseluruhan alat perkakas dan bahan yang dihadapi, lingkungan sekitarnya di mana seseorang bekerja, metode kerjanya, serta pengaturan kerjanya baik sebagai perseorangan maupun sebagai kelompok.

Menurut Rivai (2012: 53), kepemimpinan adalah proses mempengaruhi atau memberi contoh kepada pengikut-pengikutnya lewat proses komunikasi dalam upaya mencapai tujuan organisasi. Kepemimpinan menyangkut proses pengaruh sosial yang disengaja dijalankan oleh seseorang terhadap orang lain untuk menstruktur aktivitas dan pengaruh didalam kelompok atau organisasi. Kemampuan pemimpin dalam menggerakkan dan memberdayakan pegawainya akan berpengaruh terhadap kinerja pegawai. Perubahan lingkungan dan tehnologi yang cepat meningkatkan kompleksitas tantangan yang dihadapi oleh organisasi, hal ini memunculkan kebutuhan organisasi 
terhadap pemimpin yang dapat mengarahkan dan mengembangkan usaha-usaha bawahan dengan kekuasaan yang dimiliki untuk mencapai tujuan organisasi dalam membangun organisasi menuju high performance.

Dinas Perdagangan dan Perindustrian Kabupaten Musi Banyuasin di Pimpin oleh seorang kepala dinas yang berada dan bertanggung jawab kepada Bupati melalui Sekretaris Daerah. Dinas Perdagangan dan Perindustrian Kabupaten Musi Banyuasin mempunyai tugas melaksanakan tugas pokok pemerintah di bidang Perdagangan dan Perindustrian sesuai dengan kewenangannya dan tugas lain yang dilimpahkan oleh Bupati.

Hasil pemantauan penulis di lapangan kurangnya perhatian pimpinan dalam membimbing, mengarahkan ataupun memberdayakan para pegawainya untuk lebih bersemangat dalam bekerja serta kurangnya pimpinan dalam memberikan penghargaan (rewards) terhadap hasil kerja pegawai dan kurang tegasnya pimpinan dalam memberikan sanksi terhadap pelanggaran yang dilakukan pegawai. Hal inilah yang menyebabkan kinerja pegawai tidak optimal.

Penyebab turunnya kinerja pegawai berikutnya adalah lingkungan kerja, berdasarkan hasil survei peneliti mengenai kondisi lingkungan kerja pegawai, terlihat bahwa lingkungan kerja pada kantor ini belum cukup baik hal ini ditandai dengan banyaknya lampu yang ada ruang kerja pegawai mati atau kurangnya penerangan di ruang kerja, suhu udara pada tiap ruang kerja kurang dingin hal ini disebabkan adanya AC yang rusak sehingga kebanyakan pegawai merasa kurang nyaman bekerja di ruangan dan sering keluar ruangan karena kepanasan dan tata ruang kerja pegawai tidak teratur atau kurang rapi terlihat banyaknya berkas-berkas tidak tersusun rapi.

Berdasarkan uraian latar belakang di atas, hal tersebut tentunya harus segera dibenahi agar para pimpinan dan bawahan pada organisasi dapat memberikan pelayanan yang prima kepada masyarakat secara lebih profesional. Dengan adanya fenomena tersebut, maka penulis mengajukan penelitian dengan judul "Pengaruh Lingkungan Kerja Dan Kepemimpinan Terhadap Kinerja Pegawai Pada Dinas Perdagangan dan Perindustrian Kabupaten Musi Banyuasin’”.

\section{Rumusan Masalah}

Berdasarkan fenomena yang telah dikemukakan maka rumusan masalah dalam penelitian ini adalah bagaimana pengaruh lingkungan kerja dan kepemimpinan terhadap kinerja pegawai nada Dinas Perdagangan dan Perindustrian Kabupaten Musi Banyuasin?

\section{Tujuan Penelitian}

Adapun tujuan dari penelitian ini adalah untuk mengetahui pengaruh lingk rerja dan kepemimpinan terhadap kinerja pegawai pada Dinas Perdagangan dan Perindustrian Kabupaten Musi Banyuasin.

\section{Kajian Pustaka}

\section{Pengertian Manajemen}

Menurut Griffin (2010: 5), manajemen adalah proses perencanaan / planning, pengorganisasian, pengkoordinasisasian, serta pengontrolan setiap sumber daya yang ada guna mencapai tujuan ataupun goals yang telah ditentukan dengan efektif dan efisien. Efektif berarti tujuan dapat dicapai sesuai dengan rencana yang ada, dan efisien berarti dilaksanakan dengan benar dan terorganisis yang sesuai dengan jadwal yang telah ditentukan.

Sedangkan menurut Terry (2011: 11), manajemen adalah suatu proses unik dan khas yang terdiri atas tindakan-tindakan perencanaan, pengorganisasian, serta penggerakan dan pengendalian yang dilakukan guna menentukan arah serta mencapai tujuan yang telah ditentukan sebelumnya melalui pemanfaatan SDM serta sumber daya lain. Adapun fungsi manajemen dapat dibagi menjadi :

a. Perencanaan

Planning (perencanaan) ialah penetapan pekerjaan yang harus dilaksanakan oleh kelompok untuk mencapai tujuan yang digariskan.

b. Pengorganisasian

Organizing berasal dari kata organon dalam bahasa Yunani yang berarti alat, yaitu proses pengelompokan kegiatan-kegiatan untuk mencapai tujuan-tujuan dan penugasan setiap kelompok kepada seorang manajer.

c. Pelaksanaan

Pelaksanaan merupakan usaha menggerakkan anggota-anggota kelompok sedemikian rupa, hingga mereka berkeinginan dan berusaha untuk mencapai tujuan yang telah direncanakan bersama. 
d. Pengawasan

Controlling atau pengawasan adalah penemuan dan penerapan cara dan alat utk menjamin bahwa rencana telah dilaksanakan sesuai dengan rencana yang telah ditetapkan.

\section{Pengertian Manajemen Sumber Daya Manusia}

Menurut Mangkunegara (2010: 04), mengatakan bahwa manajemen sumber daya manusia merupakan suatu perencanaan, pengorganisasian, pengkoordinasian, pelaksanaan, dan pengawasan terhadap pengadaan, pengembangan, pemberian balas jasa, pengintegrasian, pemeliharaan, dan pemisahan tenaga kerja dalam rangka mencapai tujuan organisasi.

Menurut Handoko (2011: 04) manajemen sumber daya manusia adalah penarikan, seleksi, pengembangan, pemeliharaan, dan penggunaan sumber daya manusia untuk mencapai baik tujuantujuan individu mauoun organisasi.

Menurut Hasibuan (2010: 8-9), mendefinisikan manajemen sumber daya manusia adalah ilmu dan seni yang mengatur hubungan dan peranan tenaga kerja agar efektif dan efisien membantu terwujudnya tujuan perusahaan, karyawan dan masyarakat. Adapun fungsi-fungsi manajemen sumber daya manusia adalah :

a. Perencanaan

b. Pengorganisasian

c. Pengarahan

d. Pengendalian

e. Pengadaan

f. Pengembangan

g. Kompensasi

h. Pengintegrasian

i. Pemeliharaan

j. Kedisiplinan

k. Pemberhentian

\section{Lingkungan Kerja}

Menurut Sofyan (2013: 19), lingkungan kerja adalah segala sesuatu yang berada di sekitar para pekerja dan yang dapat mempengaruhi dirinya dalam menjalankan tugas-tugas yang diembankan kepada karyawan.

Menurut Wursanto dalam Hendri (2012: 3-4), Lingkungan kerja dibedakan menjadi dua macam, yaitu kondisi lingkungan kerja yang menyangkut segi fisik dan non fisik. Lingkungan kerja fisik adalah tempat kerja pegawai melakukan aktivitasnya, lingkungan kerja fisik mempengaruhi semangat dan emosi kerja para karyawan. Faktor-faktor fisik ini mencakup suhu udara di tempat kerja, luas ruang kerja, kebisingan, kepadatan, dan kesesakan. Faktor-faktor fisik ini sangat mempengaruhi tingkah laku manusia, selanjutnya peningkatan suhu dapat menghasilkan kenaikan prestasi kerja tetapi dapat pula malah menurunkan prestasi kerja. Sedangkan lingkungan kerja non fisik merupakan lingkungan kerja yang tidak dapat ditangkap dengan panca indera, seperti warna, bau, suara, dan rasa.

Menurut Sedarmayati (2011: 28), lingkungan kerja adalah keseluruhan alat perkakas dan bahan yang dihadapi, lingkungan sekitarnya di mana seseorang bekerja, metode kerjanya, serta pengaturan kerjanya baik sebagai perseorangan maupun sebagai kelompok. Adapun Faktor-faktor lingkungan kerja yang dapat mempengaruhi terbentuknya suatu kondisi lingkungan kerja yaitu :

a. Penerangan /cahaya

b. Suhu Udara

c. Suara bising

d. Tata Ruang

e. Hubungan Karyawan

Berdasarkan pendapat Sedarmayati (2011: 28), indikator yang digunakan untuk mengukur lingkungan kerja adalah :

a. Penerangan/cahaya yaitu kebutuhan cahaya yang ada di ruang kerja dan perangan lampu listrik pada saat kondisi cuaca mendung dan malam.

b. Suhu udara yaitu sirkulasi udara dan kondisi AC pada tiap ruang kerja.

c. Suara bising yaitu suara yang datang dari dalam maupun diluar kantor. 
d. Tata ruang yaitu kesesuaian jumlah pegawai pada ruang kerja dan kenyaman pegawai dalam bekerja

e. Hubungan pegawai yaitu hubungan antara pegawai dengan teman sejawat serta dengan atasan.

Kepemimpinan

Menurut Robbins (2010: 49), menyatakan bahwa kepemimpinan adalah kemampuan untuk mempengaruhi suatu kelompok guna mencapai sebuah visi atau serangkaian tujuan yang ditetapkan.

Menurut Hasibuan (2009: 169), kepemimpinan merupakan kata benda dari pemimpin (leader). Pemimpin (laeder) adalah seseorang yang mempergunakan wewenang dan kepemimpinanya, mengarahkan bawahan untuk mengerjakan sebagian pekerjaanya dan mencapai tujuan organisasi.

Menurut Rivai (2012: 53), kepemimpinan adalah proses mempengaruhi atau memberi contoh kepada pengikut-pengikutnya lewat proses komunikasi dalam upaya mencapai tujuan organisasi. seorang pemimpin dalam mengimplementasikan kepemimpinannya harus mampu secara dewasa melaksanakan kedewasaan terhadap instansi atau organisasinya, kepemimpinan dibagi kedalam lima dimensi dan sembilan indikator, yaitu :

a. Kemampuan untuk membina kerjasama dan hubungan yang baik seperti membina kerjasama dan hubungan baik dengan bawahan dalam pelaksanaan tugas yang menjadi tanggung jawab masingmasing dan kemampuan seorang pemimpin dalam memotivasi bawahannya.

b. Kemampuan yang efektivitas seperti mampu menyelesikan tugas diluar kemampuan, menyelesaikan tugas tepat waktu danhadir tepat waktu dan tidak terlambat.

c. Kepemimpinan yang partisipatif seperti pengambilan keputusan secara musyawarah, dapat menyelesaikan masalah secara tepat dan mampu dalam meniliti masalah yang terjadi pada pekerjaan

d. Kemampuan dalam mendelegasikan tugas atau waktu seperti bersedia untuk membawa kepentingan pribadi dan organisasi kepada kepentingan yang lebih luas, yaitu kepentingan organisasi menggunakan waktu sisa untuk keperluan pribadi dan mampu dalam menyelesaikan tugas sesuai dengan target.

e. Kemampuan dalam mendelegasikan tugas atau wewenang seperti tanggung jawab seorang pemimpin dalam menyelesaikan tugas mana yang harus ditangani sendiri dan mana yang harus ditangani secara kelompok dan memberikan bimbingan dan pelatihan dalam pengambilan keputusan.

\section{Kinerja Pegawai}

Menurut Sofyan (2013: 19), kinerja dapat diartikan suatu ukuran perbandingan, baik buruknya aktivitas organisasi melalui hasil-hasil yang dicapai (output) sesuai dengan tujuan organisasi. Intinya batasan maupun yang akan digunakan, penilaian individu selalu diartikan sebagai suatu proses yang sistematis, dimana atasan mengkaji dan menilai kemampuan, prilaku kerja dan hasil kerja.

Menurut Wibowo (2014: 2), kinerja adalah nilai serangkaian perilaku pekerja yang memberikan kontribusi, baik secara positif atau negatif, pada penyelesaiaan tujuan organisasi. Kinerja organisasi juga ditunjukan oleh bagaimana berlangsungnya kegiatan untuk mencapai tujuan tersebut. Didalam proses pelaksanaan aktivitas harus selalu dilakukan monitoring, penilaian, dan review atau peninjauan ulang terhadap kinerja sumber daya manusia. Melalui monitoring dilakukan pengukuran dan penilaian kinerja secara periodik untuk mengetahui pencapaian kemajuan kinerja dilakukan prediksi apakah terjadi deviasi pelaksanaan terhadap rencana yang dapat mengganggu pencapaian tujuan. Adapun ukuran kinerja untuk seorang plant manager dapat dinyatakan dalam bentuk berikut :

a. Kuantitas, dinyatakan dalam bentuk jumlah output, atau persentase antara output aktual dengan output yang menjadi target.

b. Kualitas, dinyatakan dalam bentuk pengawasan kualitas yang bervariasi di luar batas, jumlah keluhan yang masih dalam batas yang dapat dipertimbangkan untuk ditoleransikan.

c. Kepuasan, diukur sebagai output per pekerjaan.

d. Ketepatan waktu, dinyatakan dalam bentuk pencapaian batas waktu pengiriman, jumlah unit yang dapat diselesaikan tepat waktu.

e. Pengawasan biaya, sebagai biaya per unit produksi, variasi upah bur langsung atau tidak langsung. 
Menurut Bangun (2012: 231), kinerja adalah hasil pekerjaan yang dicapai seseorang berdasarkan persyaratan-persyaratan pekerjaan. Suatu pekerjaan mempunyai persyaratan tertentu untuk dapat dilakukan dalam mencapai tujuan yang disebut juga sebagai standar pekerjaan. Suatu pekerjaan dapat diukur melalui jumlah, kualitas, ketepatan waktu mengerjakannya, kehadiran, kemampuan bekerja sama yang dituntut suatu pekerjaan, adapu penjelasan pengukuran tersebut sebagai berikut :
a. Jumlah Pekerjaan
b. Kualitas pekerjaan
c. Ketepatan waktu
d. Kehadiran
e. Kemampuan kerja sama
Penelitian Terdahulu

Berdasarkan penelitian yang telah dilakukan oleh Suwesty Yunia Pratiwi (2011), dengan judul penelitian 'Pengaruh Kepemimpinan Dan Lingkungan Kerja Terhadap Kinerja Karyawan Melalui Kepuasan Kerja Sebagai Variabel Intervening (Studi Pada Perusahaan Daerah Air Minum Kabupaten Wonosobo)', Dari hasil penelitian didapatkan Dari hasil analisis jalur pada penelitian, menunjukkan bahwa pengaruh secara langsung variabel kepemimpinan dan variabel lingkungan kerja terhadap kinerja lebih besar dibandingkan pengaruh variabel kepemimpinan dan variabel lingkungan kerja terhadap kinerja melalui kepuasan kerja (secara tidak langsung). Hal ini dapat diartikan bahwa variabel kepemimpinan dan variabel lingkungan kerja dapat secara langsung mempengaruhi kinerja tanpa melalui kepuasan kerja sebagai variabel intervening.

Berdasarkan penelitian yang telah dilakukan oleh Tri Widodo (2010). Dengan judul penelitian 'Pengaruh Lingkungan Kerja, Budaya Organisasi, Kepemimpinan Terhadap Kinerja (Studi pada Pegawai Kecamatan Sidorejo Kota Salatiga)'. Dari hasi penelitian di ketahui bahwa hasil perhitungan uji $\mathrm{F}$ ternyata Fhitung 16,594 dan Ftabel $(0,05 ; 3,56)=$ 4,16 , oleh karena itu, hasil analisis data menunjukkan bahwa $F_{\text {hitung }}>F_{\text {tabel }}(0,05 ; 3,56)$. Kesimpulan yang dapat diambil adalah $\mathrm{H} 0$ ditolak dan Ha diterima, sehingga hipotesis yang menyatakan bahwa "ada pengaruh yang signifikan antara variabel lingkungan kerja, budaya organisasi, dan kepemimpinan terhadap kinerja pegawai Kecamatan Sidorejo Kota Salatiga, diterima kebenaranya

\section{Kerangka Pemikiran}

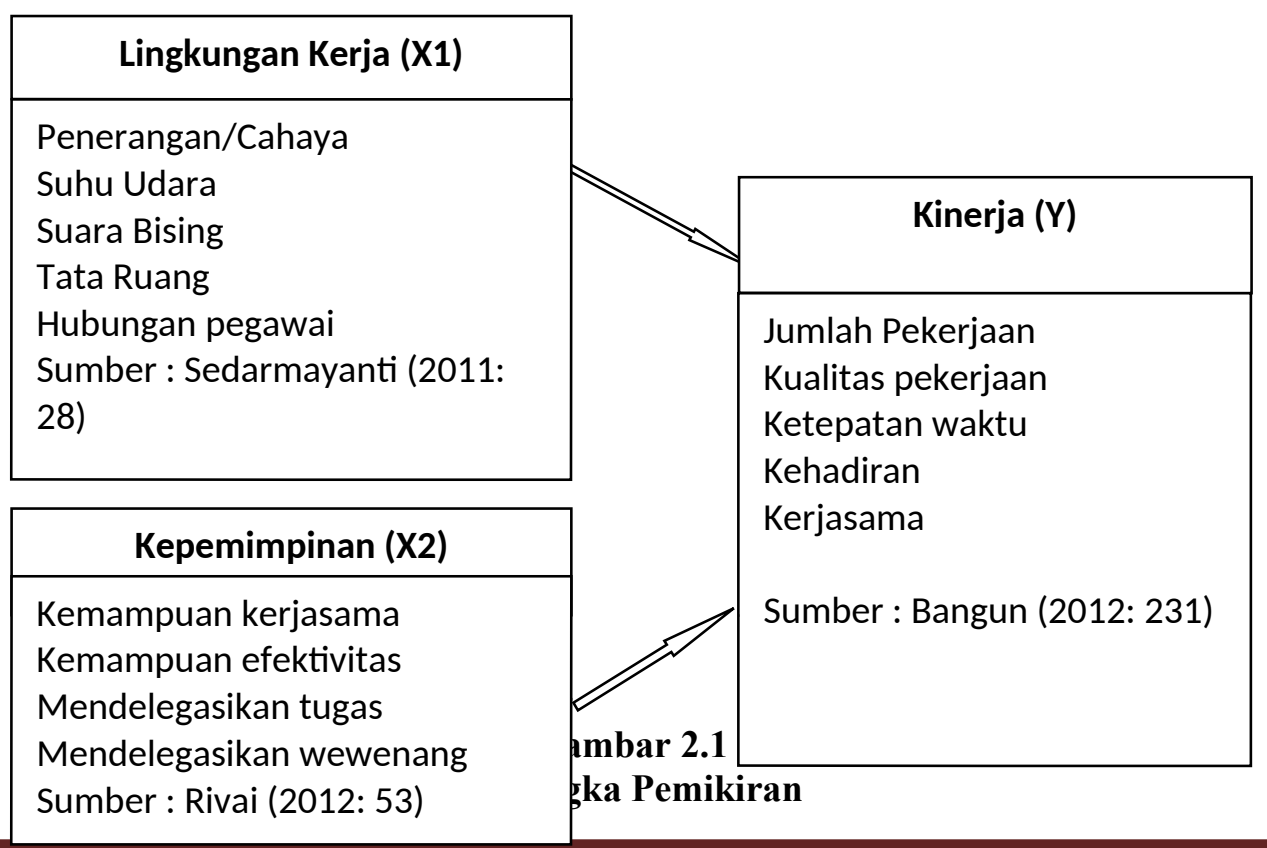


Berdasarkan gambar kerangka pemikiran diatas dapat dijelaskan bahwa sala satu faktor untuk meningkatkan kerja pegawai pada suatu organisasi adalah dengan cara memperbaiki linokıngan kerja disekitar pegawai seperti penerangan di tempat kerja, suhu udara, suara bisin: lang dan hubungan antara pegawai serta kepemimpinan harus bekerja sama, memiliki kemaınuau efektivitas, mendelegasikan tugas dan wewenang.

\section{Hipotesis}

Adapun hipotesis yang diajukan pada penelitian ini adalah : Adanya pengaruh lingkungan kerja dan kepemimpinan terhadap kinerja pegawai pada Dinas Perdagangan dan Perindustrian Kabupaten Musi Banyuasin.

\section{Metode Penelitian}

\section{Lokasi dan Waktu Penelitian}

Lokasi penelitian ini adalah Dinas Perdagangan dan Perindustrian Kabupaten Musi Banyuasin yang berlamat di jalan Merdeka Lingkungan VII Kelurahan Serasan Jaya. Sedangkan untuk waktu penelitian ini dilakukan kurang lebih 5 (lima) bulan.

\section{Desain Penelitian}

Desain penelitian atau rangcangan penelitian harus disusun terlebih dahulu sebelum peneliti melaksanakan penelitian. Adapun desain dalam penelitian ini penulis menggunakan desain penelitian kausalitas yaitu: desain penelitian yang disusun untuk meneliti kemungkinan adanya hubungan sebab-akibat antara variabel.

\section{Jenis dan Sumber Data}

\section{a. Data Primer}

b. Data Sekunder

\section{Teknik Pengumpulan Data}

Menurut Sunyoto (2013: 63), untuk mendapatkan informasi dan data-data yang diperlukan penulis, maka teknik yang digunakan penulis untuk mengumpulkan data dalam penelitian ini adalah :
a. Kuesioner
b. Wawancara
c. Studi Dokumentasi
Operasionalisasi Variabel Penelitian

Operasionalisasi Variabel

\begin{tabular}{|c|c|c|c|c|}
\hline Variabel & Definisi Variabel & Indikator & $\begin{array}{c}\text { Nomor } \\
\text { Pertanyaan }\end{array}$ & $\begin{array}{l}\text { Skala } \\
\text { ukur }\end{array}$ \\
\hline $\begin{array}{l}\text { Lingkungan } \\
\text { Kerja }\left(X_{1}\right)\end{array}$ & $\begin{array}{l}\text { Menurut Sedarmayati } \\
(2011: \text { 28), lingkungan } \\
\text { kerja adalah keseluruhan } \\
\text { alat perkakas dan bahan } \\
\text { yang dihadapi. }\end{array}$ & $\begin{array}{l}\text { a. Penerangan } \\
\text { b. Suhu Udara } \\
\text { c. Suara Bising } \\
\text { d. Tata Ruang } \\
\text { e. Hubungan }\end{array}$ & $\begin{array}{c}1-2 \\
3-4 \\
5-6 \\
7-8 \\
9-10\end{array}$ & Likert \\
\hline Variabel & Definisi Variabel & Indikator & $\begin{array}{c}\text { Nomor } \\
\text { Pertanyaan }\end{array}$ & $\begin{array}{l}\text { Skala } \\
\text { ukur }\end{array}$ \\
\hline $\begin{array}{l}\text { Kepemimpin } \\
\text { an }\left(\mathrm{X}_{2}\right)\end{array}$ & $\begin{array}{l}\text { Menurut Rivai (2012: } 53) \text {, } \\
\text { kepemimpinan adalah } \\
\text { proses mempengaruhi } \\
\text { atau memberi contoh } \\
\text { kepada pengikut- } \\
\text { pengikutnya lewat proses } \\
\text { komunikasi dalam upaya } \\
\text { mencapai } \\
\text { organisasi. tujuan }\end{array}$ & $\begin{array}{l}\text { a. Kemampuan } \\
\text { kerjasama } \\
\text { b. Kemampuan } \\
\text { efektivitas } \\
\text { c. Mendelegasik } \\
\text { an tugas } \\
\text { d. Mendelegasik } \\
\text { an wewenang }\end{array}$ & $\begin{array}{l}1-2 \\
3-4 \\
5-7 \\
9-10\end{array}$ & Likert \\
\hline Kinerja (Y) & $\begin{array}{l}\text { Menurut Bangun (2012: } \\
\text { 231), kinerja adalah hasil }\end{array}$ & $\begin{array}{ll}\text { a. } & \text { Jumlah } \\
\text { Pekerjaan }\end{array}$ & $1-2$ & Likert \\
\hline
\end{tabular}


Vol. 2 No. 2 Desember 2019, 75-91

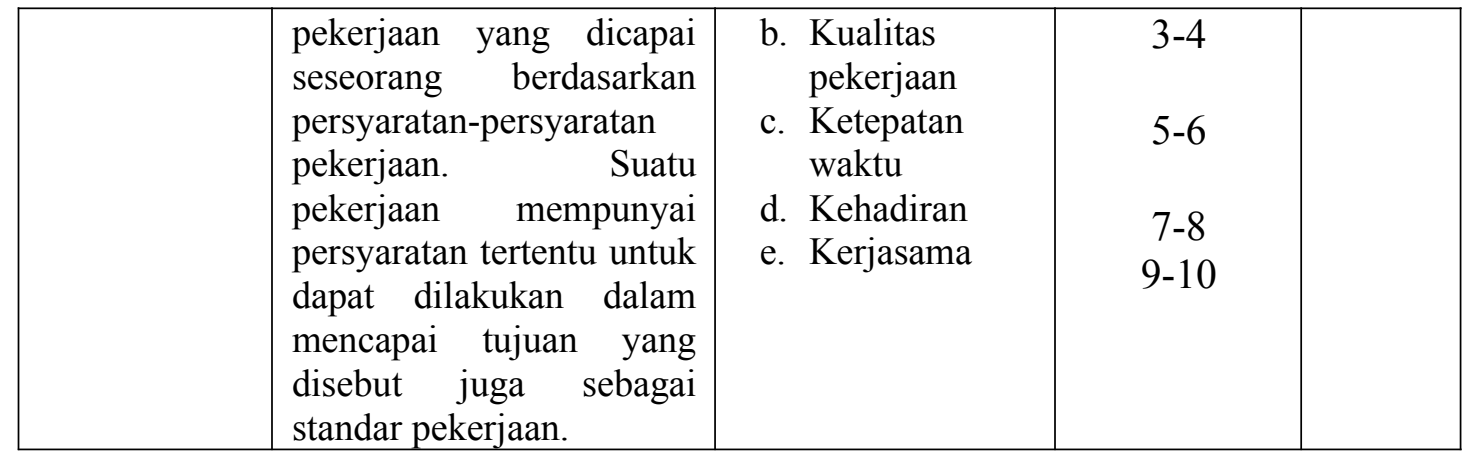

\section{Populasi, Sampel dan Teknik Pengambilan Sampel}

Populasi dalam penelitian ini adalah seluruh pegawai pada Dinas Perdagangan dan Perindustrian Kabupaten Musi Banyuasin yang berjumlah 104 pegawai yang terdiri dari 30 orang Pegawai Negeri Sipil (PNS) dan 74 orang Tenaga Kerja Sukarela (TKS).

Dalam penentuan jumlah sampel dari populasi penulis menggunakan rumus Slovin dalam Sugiyono (2011: 145). untuk populasi 104 orang dengan tingkat kesalahan 5\%. Adapun rumus Slovin untuk menghitung ukuran sampel dari populasi yang diketahui jumlahnya adalah sebagai berikut :

$n=\frac{N}{1+N e^{2}}$

$$
n=\frac{104}{1+104 \times 0,05^{2}}
$$

$n=\frac{104}{1+0,26}$

$n=\frac{104}{1,26}$

$n=i 82,54$ atau 83

Jadi sampel dalam penelitian ini berjumlah 83 responden

Keterangan :

$\mathrm{n} \quad=$ ukuran sampel

$\mathrm{N}=$ ukuran populasi

e $\quad$ batas toleransi kesalahan (error tolerance)

Adapun pengambilan sampel dalam penelitian ini dilaksanakan dengan menggunakan metode non-probability sampling (pengambilan sampel secara tidak acak) dengan menggunakan teknik pengambilan sampel purposive sampling, dimana sampel dipilih berdasarkan karikteristik. Karikteristik tersebut adalah semua Pegawai Disperindag Kabupaten Musi Banyuasin yang terdiri dari

a. Pegawai Negeri Sipil (PNS)

b. Pegawai Tenaga Kerja Kontrak (TKS)

\section{Teknik Pengelolaan Data}

\section{Uji Validitas}

Menurut Bandur (2013: 199), uji validitas dilakuan dengan membandingkan nilai $r$ hitung dengan $r$ tabel untuk tingkat signifikansi 5 persen dari degree of freedom $(\mathrm{df})=\mathrm{n}-2$, dalam hal ini $n$ adalah jumlah sampel. Jika $r$ hitung $>r$ tabel maka pertanyaan atau indikator tersebut dinyatakan valid, demikian sebaliknya bila $\mathrm{r}$ hitung $<\mathrm{r}$ tabel maka pertanyaan atau indikator tersebut dinyatakan tidak valid.

\section{Uji Reliabilitas}

Suatu kuesioner dikatakan reliable atau handal jika jawaban seseorang terhadap pernyataan adalah konsisten atau stabil dari waktu ke waktu. Pengukuran reliabilitas dilakukan dengan cara one shot atau pengukuran sekali saja dengan alat bantu SPSS uji statistik Cronbach Alpha ( $\alpha$ ). Untuk pengambilan keputusan uji reabilitas bisa menggunakan batasan 0,6, menurut Sekaran dalam Menurut Bandur (2013: 25), reabilitas kurang dari 0.6 adalah kurang baik, sedangkan 0.7 dapat diterima dan diatas 0.8 adalah baik. 


\section{Uji Asumsi Klasik}

\section{Uji Normalitas}

Menurut Bandur (2013: 31) adalah jika nilai signifikansi lebih besar dari 0,05 maka data tersebut berdistribusi normal. Sebaliknya, jika nilai signifikansi lebih kecil dari 0,05 maka data tersebut tidak berdistribusi normal.

\section{Uji Linearitas}

Adapun dasar pengambilan keputusan pada Linearitas dapat dilakukan dengan dua cara yaitu :

a. Dengan melihat nilai signifikansi :

b. Dengan melihat $\mathrm{f}_{\text {hitung }}$ dan $\mathrm{F}_{\text {tabel }}$ :

\section{Uji Multikolinearitas}

Pengujian multikolinearitas bertujuan untuk mengetahui hubungan yang sempurna antar variabel bebas dalam model regresi. Adapun dasar pengambilan keputusan pada multikolinearitas dapat dilakukan dengan dua cara yaitu :

a. Melihat nilai tolerance :

b. Melihat nilai VIF (Variance Inflation Factor) :

\section{Uji Heteroskedastisitas} adalah :

Adapun dasar pengambilan dalam pengujian heteroskedastisitas dengan metode rank spearma

a. Jika nilai signifikansi atau sig. (2-tailed) $>$ dari nilai 0,05 maka dapat dikatan tidak terdapat masalah heteroskedastisitas.

b. Jika nilai signifikansi atau sig. (2-tailed) $<$ dari nilai 0,05 maka dapat dikatan tidak terdapat masalah heteroskedastisitas.

Regresi Linier Berganda

Menurut Sunyoto (2013: 119), persamaan regresi linier berganda adalah :

$$
\mathrm{Y}=a+\mathrm{b}_{1} \mathrm{X}_{1}+\mathrm{b}_{2} \mathrm{X}_{2}+\mathrm{e}
$$

Keterangan :

$\mathrm{Y}=$ Variabel dependen (kinerja pegawai)

$\mathrm{a}=$ Konstanta

$\mathrm{b} 1, \mathrm{~b} 2$ = Koefisien regresi

$\mathrm{X}_{1}=$ Variabel independen (lingkungan kerja)

$\mathrm{X}_{2}=$ Variabel independen (kepemimpinan)

$\mathrm{e}=$ error $/$ variabel pengganggu.

\section{Koefisien Determinan $\left(R^{2}\right)$}

Nilai koefisien determinasi ditentukan dengan nilai adjusted $R$ square. Adapun pedoman untuk memberikan interprestasi koefisien korelasi adalah :

a. Jika korelasi 0,0 sampai 0,199 hubungannya sangat rendah.

b. Jika korelasi 0,20 sampai 0,399 hubungannya rendah.

c. Jika korelasi 0,40 sampai 0,599 hubungannya sedang.

d. Jika korelasi 0,60 sampai 0,799 hubungannya kuat.

e. Jika korelasi 0,80 sampai 1,000 sangat kuat.

\section{Pengujian Hipotesis}

\section{Uji Hipotesis Secara Parsial (Uji Statistik t)}

Dasar pengambilan keputusan Menurut Bandur (2013: 279), adalah dengan menggunakan angka probabilitas signifikansi yaitu :

a. Apabila signifikansi $\mathrm{t}<0,05$ atau $\mathrm{t}$ hitung $\leq \mathrm{t}$ tabel, maka $\mathrm{H}_{\mathrm{o}}$ diterima dan $\mathrm{H}_{\mathrm{a}}$ ditolak. Artinya tidak ada pengaruh lingkungan kerja dan kepemimpinan terhadap kinerja pegawai pada Dinas Perdagangan dan Perindustrian Kabupaten Musi Banyuasin.

b. Apabila signifikansi $\mathrm{t}>0,05$ atau $\mathrm{t}$ hitung $>\mathrm{t}$ tabel, maka $\mathrm{H}_{\mathrm{o}}$ ditolak dan $\mathrm{H}_{\mathrm{a}}$ diterima. Artinya ada pengaruh lingkungan kerja dan kepemimpinan terhadap kinerja pegawai pada Dinas Perdagangan dan Perindustrian Kabupaten Musi Banyuasin.

Uji Hipotesis Secara Simultan (Uji F) 
Vol. 2 No. 2 Desember 2019, 75-91

Dalam penelitian ini penulis menggunakan taraf signifikan 5\%. Adapun hipotesis yang digunakan adalah :

Ho : Variabel bebas yaitu tidak ada pengaruh lingkungan kerja dan kepemimpinan terhadap kinerja pegawai

Ha : Variabel bebas yaitu ada pengaruh lingkungan kerja dan kepemimpinan terhadap kinerja pegawai

Adapun dasar pengambilan keputusannya dalam menentukan uji f dapat menggunakan angka probabilitas signifikansi, yaitu :

a. Apabila probabilitas signifikansi $>0.05$, maka $\mathrm{H}_{\mathrm{o}}$ diterima dan $\mathrm{H}_{\mathrm{a}}$ ditolak.

b. Apabila probabilitas signifikansi $<0.05$, maka $\mathrm{H}_{\mathrm{o}}$ ditolak dan $\mathrm{H}_{\mathrm{a}}$ diterima.

\section{Hasil dan Pembahasan}

Hasil

Umur Responden

\begin{tabular}{|c|c|c|}
\hline Umur (Tahun) & Jumlah Responden & Persentase \\
\hline $20-30$ & 29 & 34,94 \\
\hline $31-40$ & 36 & 43,37 \\
\hline $41-50$ & 18 & 21,69 \\
\hline Total & 83 & 100 \\
\hline
\end{tabular}

Sumber: Data primer yang diolah, 2018

Hal ini menunjukkan bahwa pegawai pada Dinas Perdagangan dan Perindustrian Kabupaten Musi Banyuasin sebagian besar masih berusia muda.

Jenis Kelamin Responden

\begin{tabular}{|c|c|c|}
\hline Jenis Kelamin & Jumlah Responden & Persentase \\
\hline Laki-laki & 46 & 55,42 \\
\hline Perempuan & 37 & 44,58 \\
\hline Total & 83 & 100 \\
\hline
\end{tabular}

Sumber: Data primer yang diolah, 2018

Hal ini menunjukkan bahwa jenis kelamin laki-laki sebagai proporsi yang lebih besar dibanding pegawai perempuan yang ada pada Dinas Perdagangan dan Perindustrian Kabupaten Musi Banyuasin.

Pendidikan Responden

\begin{tabular}{|c|c|c|}
\hline Jenis Pendidikan & Jumlah Responden & Persentase \\
\hline SMA & 31 & 37,35 \\
\hline D3 & 17 & 20,48 \\
\hline S1 & 28 & 33,73 \\
\hline S2 & 7 & 8,43 \\
\hline Total & 83 & 100 \\
\hline
\end{tabular}

Sumber: Data primer yang diolah, 2018

Hal ini menunjukkan bahwa jumlah pegawai pada Dinas Perdagangan dan Perindustrian Kabupaten Musi Banyuasin sebagian besar memiliki pendidikan tinggi.

Deskripsi Variabel Lingkungan Kerja

Tanggapan Responden Mengenai Lingkungan Kerja $\left(\mathrm{X}_{1}\right)$

\begin{tabular}{|c|c|c|c|c|c|c|c|}
\hline No. & Pernyataan & STS & TS & $\mathbf{N}$ & $\mathbf{S}$ & SS & \multirow{2}{*}{ Total } \\
\hline $\mathbf{A}$ & \multicolumn{6}{|l|}{ Penerangan/ cahaya } & \\
\hline 1 & $\begin{array}{l}\text { Saya merasa sinar matahari sudah } \\
\text { memenuhi syarat kebutuhan } \\
\text { penerangan dalam ruang kerja. }\end{array}$ & 0 & 0 & 13 & 38 & 32 & 83 \\
\hline 2 & $\begin{array}{l}\text { Saya merasa penerangan lampu } \\
\text { listrik pada saat mendung maupun } \\
\text { malam hari sudah memadai. }\end{array}$ & 0 & 0 & 9 & 31 & 43 & 83 \\
\hline B & \multicolumn{6}{|l|}{ Suhu Udara } & \\
\hline 3 & Saya merasa sirkulasi udara di & 0 & 0 & 8 & 52 & 23 & 83 \\
\hline
\end{tabular}


Vol. 2 No. 2 Desember 2019, 75-91

\begin{tabular}{|c|c|c|c|c|c|c|c|}
\hline & $\begin{array}{l}\text { ruangan tempat bekerja sudah } \\
\text { memenuhi standar. }\end{array}$ & & & & & & \\
\hline 4 & $\begin{array}{l}\text { Saya merasa masih memerlukan alat } \\
\text { pengatur suhu udara }(\mathrm{AC}) \text { di ruangan } \\
\text { tempat bekerja. }\end{array}$ & 0 & 1 & 9 & 36 & 37 & 83 \\
\hline $\mathbf{C}$ & \multicolumn{6}{|l|}{ Suara Bising } & \\
\hline 5 & $\begin{array}{l}\text { Saya merasa terganggu terhadap } \\
\text { suara aktivitas masyarakat yang } \\
\text { sedang melakukan aktivitas kerja } \\
\text { diluar kantor }\end{array}$ & 0 & 0 & 7 & 28 & 48 & 83 \\
\hline 6 & $\begin{array}{l}\text { Saya merasa terganggu akibat suara } \\
\text { dari dalam ruangan tempat bekerja. }\end{array}$ & 0 & 0 & 12 & 35 & 36 & 83 \\
\hline $\mathbf{D}$ & \multicolumn{6}{|l|}{ Tata Ruang } & \\
\hline 7 & $\begin{array}{l}\text { Tata ruang kerja saya rapih membuat } \\
\text { saya nyaman }\end{array}$ & 0 & 0 & 13 & 45 & 25 & 83 \\
\hline 8 & $\begin{array}{l}\text { Ruangan kerja saya telah sesuai } \\
\text { dengan jumlah orang yang bekerja. }\end{array}$ & 0 & 0 & 12 & 29 & 42 & 83 \\
\hline e & \multicolumn{6}{|l|}{ Hubungan Pegawai } & \\
\hline 9 & $\begin{array}{l}\text { Hubungan antara sejawat dengan } \\
\text { pimpinan berjalan baik. }\end{array}$ & 3 & 3 & 9 & 23 & 45 & 83 \\
\hline 10 & $\begin{array}{l}\text { Pimpinan memutuskan sendiri kebijakan } \\
\text { tanpa didiskusikan terlebih dahulu } \\
\text { dengan Pegawai. }\end{array}$ & 2 & 2 & 13 & 29 & 37 & 83 \\
\hline
\end{tabular}

Sumber: Data primer yang diolah, 2018

Hal ini menunjukkan adanya penilaian terhadap lingkungan kerja yang tinggi yang dimiliki pegawai pada Dinas Perdagangan dan Perindustrian Kabupaten Musi Banyuasin.

Deskripsi Variabel Kepemimpinan

Tanggapan Responden Mengenai Kepemimpinan $\left(\mathbf{X}_{2}\right)$

\begin{tabular}{|c|c|c|c|c|c|c|c|}
\hline No. & Pernyataan & STS & TS & $\mathbf{N}$ & $\mathbf{S}$ & SS & \multirow{2}{*}{ Total } \\
\hline $\mathbf{a}$ & \multicolumn{6}{|l|}{ Kemampuan Kerjasama } & \\
\hline 1 & $\begin{array}{l}\text { Pimpinan selalu menunjukkan } \\
\text { kecerdasan dan intelektualitas } \\
\text { berfikir dalam proses kinerja. }\end{array}$ & 7 & 17 & 28 & 19 & 12 & 83 \\
\hline 2 & $\begin{array}{lcr}\text { Pimpinan selalu memantau } \\
\text { tindakan pegawai } & \text { dalam } \\
\text { menyelesaikan tugas pegawai }\end{array}$ & 3 & 7 & 23 & 27 & 23 & 83 \\
\hline b & \multicolumn{6}{|l|}{ Kamampuan Efektivitas } & \\
\hline 3 & $\begin{array}{l}\text { Pimpinan selalu membangkitkan } \\
\text { rasa saling menghargai pendapat } \\
\text { sesama pegawai. }\end{array}$ & 8 & 10 & 27 & 25 & 13 & 83 \\
\hline 4 & $\begin{array}{l}\text { Pimpinan lebih mengutamakan } \\
\text { kerjasama dalam usaha mencapai } \\
\text { tujuan. }\end{array}$ & 1 & 8 & 27 & 25 & 22 & 83 \\
\hline c & \multicolumn{6}{|l|}{ Mendelegasikan Tugas } & \\
\hline 5 & $\begin{array}{l}\text { Pimpinan senang menerima saran, } \\
\text { pendapat, dan kritikan-kritikan } \\
\text { dari bawahan. }\end{array}$ & 5 & 14 & 16 & 19 & 29 & 83 \\
\hline 6 & $\begin{array}{l}\text { Pimpinan selalu memberikan } \\
\text { instruksi dengan jelas dan tegas agar } \\
\text { pekerjaan diselesaikan tepat pada }\end{array}$ & 1 & 7 & 18 & 31 & 26 & 83 \\
\hline
\end{tabular}


Vol. 2 No. 2 Desember 2019, 75-91

\begin{tabular}{|c|l|c|c|c|c|c|c|}
\hline & waktunya & & & & & & \\
\hline 7 & $\begin{array}{l}\text { Pimpinan selalu berusaha } \\
\text { mensinkronisasikan kepentingan } \\
\text { dan tujuan organisasi. }\end{array}$ & 2 & 0 & 13 & 33 & 35 & 83 \\
\hline $\mathbf{d}$ & Medelegasikan Wewenang & & & & \\
\hline 8 & $\begin{array}{l}\text { Pimpinan memperhatikan pentingnya } \\
\text { nilai-nilai karyawan dalam } \\
\text { mengkomunikasikan tujuan yang } \\
\text { dicapai. }\end{array}$ & 2 & 8 & 13 & 33 & 27 & 83 \\
\hline 9 & $\begin{array}{l}\text { Pimpinan saya selalu menselaraskan } \\
\text { dengan tujuan organisasi dengan } \\
\text { bawahanyan. }\end{array}$ & 0 & 23 & 34 & 25 & 83 \\
\hline 10 & $\begin{array}{l}\text { Pimpinan saya dalam } \\
\text { mendelegasikan wewenang tetap } \\
\text { menciptakan hubungan kerja yang } \\
\text { menyenangkan. }\end{array}$ & 5 & 8 & 21 & 31 & 18 & 83 \\
\hline
\end{tabular}

Sumber: Data primer yang diolah, 2018

Hal ini menunjukkan adanya pengaruh yang signifikan kepemimpinan terhadap kinerja pegawai pada Dinas Perdagangan dan Perindustrian Kabupaten Musi Banyuasin.

\section{Deskripsi Variabel Kinerja Pegawai}

Tanggapan Responden Mengenai Kinerja pegawai (Y)

\begin{tabular}{|c|c|c|c|c|c|c|c|}
\hline No. & Pernyataan & STS & TS & $\mathbf{N}$ & $\mathbf{S}$ & SS & \multirow{2}{*}{ Total } \\
\hline $\mathbf{a}$ & \multicolumn{6}{|l|}{ Kuantitas Pekerjaan } & \\
\hline 1 & $\begin{array}{l}\text { Semua pegawai memiliki } \\
\text { pengetahuan dan kemampuan yang } \\
\text { tinggi dalam bekerja. }\end{array}$ & 0 & 0 & 8 & 35 & 40 & 83 \\
\hline 2 & $\begin{array}{l}\text { Semua pegawai pada Disperindag } \\
\text { mempuyai pendidikan tinggi }\end{array}$ & 0 & 0 & 11 & 40 & 32 & 83 \\
\hline b & \multicolumn{6}{|l|}{ Kualitas Pekerjaan } & \\
\hline 3 & $\begin{array}{l}\text { Setiap pekerjaan yang diberikan } \\
\text { kepada pegawai } \\
\text { beban kerja }\end{array}$ & 0 & 0 & 16 & 30 & 37 & 83 \\
\hline 4 & $\begin{array}{l}\text { Pekerjaan yang diberikan kepada } \\
\text { pegawai selalu sesuai dengan } \\
\text { waktu yang telah ditetapkan } \\
\text { instansi. }\end{array}$ & 0 & 0 & 11 & 40 & 32 & 83 \\
\hline $\mathbf{c}$ & \multicolumn{6}{|l|}{ Ketepatan Waktu } & \\
\hline 5 & $\begin{array}{l}\text { Pegawai mampu menyelesaikan } \\
\text { pekerjaan yang lebih banyak dari } \\
\text { standar. }\end{array}$ & 0 & 0 & 10 & 36 & 37 & 83 \\
\hline 6 & $\begin{array}{l}\text { Pegawai dalam menyelesaikan } \\
\text { pekerjaan selalu tepat waktu }\end{array}$ & 0 & 2 & 12 & 33 & 36 & 83 \\
\hline d & \multicolumn{6}{|l|}{ Kehadiran } & \\
\hline 7 & $\begin{array}{l}\text { Pegawai datang kekantor selalu } \\
\text { hadir tepat waktu dari pada } \\
\text { pemimpin }\end{array}$ & 3 & 3 & 14 & 32 & 31 & 83 \\
\hline 8 & $\begin{array}{l}\text { Pegawai selalu hadir tepat waktu } \\
\text { pada saat masuk jam kerja. }\end{array}$ & 1 & 4 & 16 & 23 & 39 & 83 \\
\hline $\mathbf{e}$ & \multicolumn{6}{|l|}{ Kemampuan Kerja Sama } & \\
\hline 9 & $\begin{array}{l}\text { Hubungan } \\
\text { pegawai lainnya selama ini }\end{array}$ & 2 & 7 & 13 & 23 & 38 & 83 \\
\hline
\end{tabular}


JURNAL MANAJEMEN KOMPETEN

Vol. 2 No. 2 Desember 2019, 75-91

\begin{tabular}{|c|l|c|c|c|c|c|c|}
\hline & berjalan dengan baik & & & & & & \\
\hline 10 & $\begin{array}{l}\text { Hubungan bawahan dengan } \\
\text { pimpinan selama ini berjalan } \\
\text { dengan baik }\end{array}$ & 2 & 4 & 19 & 28 & 30 & 83 \\
\hline
\end{tabular}

Sumber: Data primer yang diolah, 2018

Hal ini menunjukkan adanya penilaian terhadap kinerja pegawai pada Dinas Perdagangan dan Perindustrian Kabupaten Musi Banyuasin.

\section{Uji Instrumen Data}

Pengujian Validitas

\begin{tabular}{|c|c|c|c|c|}
\hline No. & Variabel/Indikator & r hitung & $r$ table & Keterangan \\
\hline & \multicolumn{4}{|l|}{ Lingkungan Kerja $\left(\mathrm{X}_{1}\right)$} \\
\hline 1 & Item 1 & 0,710 & 0,215 & Valid \\
\hline 2 & Item 2 & 0,689 & 0,215 & Valid \\
\hline 3 & Item 3 & 0,683 & 0,215 & Valid \\
\hline 4 & Item 4 & 0,513 & 0,215 & Valid \\
\hline 5 & Item 5 & 0,665 & 0,215 & Valid \\
\hline 6 & Item 6 & 0,805 & 0,215 & Valid \\
\hline 7 & Item 7 & 0,546 & 0,215 & Valid \\
\hline 8 & Item 8 & 0,663 & 0,215 & Valid \\
\hline 9 & Item 9 & 0,600 & 0,215 & Valid \\
\hline \multirow[t]{2}{*}{10} & Item 10 & 0,481 & 0,215 & Valid \\
\hline & \multicolumn{4}{|l|}{ Kepemimpinan $\left(\mathrm{X}_{2}\right)$} \\
\hline 1 & Item 1 & 0,379 & 0,215 & Valid \\
\hline 2 & Item 2 & 0,435 & 0,215 & Valid \\
\hline 3 & Item 3 & 0,387 & 0,215 & Valid \\
\hline 4 & Item 4 & 0,381 & 0,215 & Valid \\
\hline 5 & Item 5 & 0,342 & 0,215 & Valid \\
\hline 6 & Item 6 & 0,293 & 0,215 & Valid \\
\hline 7 & Item 7 & 0,416 & 0,215 & Valid \\
\hline 8 & Item 8 & 0,249 & 0,215 & Valid \\
\hline 9 & Item 9 & 0,262 & 0,215 & Valid \\
\hline \multirow[t]{2}{*}{10} & Item 10 & 0,444 & 0,215 & Valid \\
\hline & \multicolumn{4}{|l|}{ Kinerja pegawai (Y) } \\
\hline 1 & Item 1 & 0,406 & 0,215 & Valid \\
\hline 2 & Item 2 & 0,609 & 0,215 & Valid \\
\hline 3 & Item 3 & 0,484 & 0,215 & Valid \\
\hline 4 & Item 4 & 0,455 & 0,215 & Valid \\
\hline 5 & Item 5 & 0,467 & 0,215 & Valid \\
\hline 6 & Item 6 & 0,423 & 0,215 & Valid \\
\hline 7 & Item 7 & 0,584 & 0,215 & Valid \\
\hline 8 & Item 8 & 0,587 & 0,215 & Valid \\
\hline 9 & Item 9 & 0,539 & 0,215 & Valid \\
\hline 10 & Item 10 & 0,433 & 0,215 & Valid \\
\hline
\end{tabular}

Sumber : Data primer yang diolah, 2018

Tabel diatas menunjukkan bahwa korelasi antara masing-masing indikator terhadap total skor konstruk dari setiap variabel menunjukkan hasil yang signifikan, dan menunjukkan bahwa $r$ hitung $>r$ tabel. Sehingga dapat disimpulkan bahwa semua item pernyataan dinyatakan valid.

\section{Pengujian Reliabilitas}


Vol. 2 No. 2 Desember 2019, 75-91

\begin{tabular}{|c|l|c|c|}
\hline No & \multicolumn{1}{|c|}{ Variabel } & Alpha & Keterangan \\
\hline 1 & Lingkungan Kerja $\left(\mathrm{X}_{1}\right)$ & 0,753 & Reliable \\
\hline 2 & Kepemimpinan $\left(\mathrm{X}_{2}\right)$ & 0,601 & Reliable \\
\hline 3 & Kinerja pegawai $(\mathrm{Y})$ & 0,713 & Reliable \\
\hline
\end{tabular}

Sumber : Data primer yang diolah, 2018

Hasil uji reliabilitas tersebut menunjukkan bahwa semua variabel mempunyai koefisien Alpha yang cukup besar yaitu diatas 0,60 sehingga dapat dikatakan semua konsep pengukur masing-masing variabel dari kuesioner adalah reliabel sehingga untuk selanjutnya item-item pada masing-masing konsep variabel tersebut layak digunakan sebagai alat ukur.

\section{Uji Asumsi Klasik}

\section{Uji Normalitas}

\begin{tabular}{|c|c|c|}
\hline \multicolumn{3}{|c|}{ One-Sample Kolmogorov-Smirnov Test } \\
\hline & & $\begin{array}{c}\text { Unstandardized } \\
\text { Residual }\end{array}$ \\
\hline \multicolumn{2}{|l|}{$\mathrm{N}$} & 83 \\
\hline \multirow{2}{*}{ Normal Parameters ${ }^{\mathrm{a}, \mathrm{b}}$} & Mean & $0 \mathrm{E}-7$ \\
\hline & Std. Deviation & 3,91057741 \\
\hline \multirow{3}{*}{$\begin{array}{l}\text { Most Extreme } \\
\text { Differences }\end{array}$} & Absolute &, 102 \\
\hline & Positive & 055 \\
\hline & Negative &,- 102 \\
\hline \multicolumn{2}{|l|}{ Kolmogorov-Smirnov Z } & 932 \\
\hline \multicolumn{2}{|l|}{ Asymp. Sig. (2-tailed) } & ,351 \\
\hline \multicolumn{3}{|c|}{ a. Test distribution is Normal. } \\
\hline \multicolumn{3}{|l|}{ b. Calculated from data. } \\
\hline
\end{tabular}

Sumber : Data primer yang diolah, 2018

Berdasarkan dari hasil output diatas diketahui bahwa nilai signifikansi sebesar 0,351 lebih besar dari 0,05 sehingga dapat disimpulkan bahwa data yang di uji berdistribusi normal.

\section{Uji Linearitas}

\begin{tabular}{|c|c|c|c|c|c|c|c|}
\hline \multicolumn{8}{|c|}{ ANOVA Table } \\
\hline & & & $\begin{array}{l}\text { Sum of } \\
\text { Squares }\end{array}$ & df & Mean Square & $\mathrm{F}$ & Sig. \\
\hline \multirow{5}{*}{$\begin{array}{l}\text { kinerja } \\
\text { pegawai_ } \\
\mathrm{Y}^{*} \\
\text { kepemim } \\
\text { pinan_X } \\
2\end{array}$} & \multirow{3}{*}{$\begin{array}{l}\text { Between } \\
\text { Groups }\end{array}$} & (Combined) & 319,540 & 19 & 16,818 & ,943 &, 536 \\
\hline & & Linearity & 100,531 & 1 & 100,531 & 5,636 &, 021 \\
\hline & & $\begin{array}{l}\text { Deviation from } \\
\text { Linearity }\end{array}$ & 219,008 & 18 & 12,167 &, 682 & ,815 \\
\hline & \multicolumn{2}{|c|}{ Within Groups } & 1123,689 & 63 & 17,836 & & \\
\hline & \multicolumn{2}{|l|}{ Total } & 1443,229 & 82 & & & \\
\hline
\end{tabular}

Sumber : Data primer yang diolah, 2018

Berdasarkan hasil analisis menunjukkan bahwa nilai signifikansi $(0,815)>0,05$, dan dari hasil perihitungan diperoleh nilai $\mathrm{F}_{\text {hitung }}(0,682)$, sedangkan nilai $\mathrm{F}_{\text {tabel }}(3,14)$, karena nilai signifikasi $(0,815)>0,05$ dan nilai $F_{\text {hitung }}(0,682)<\mathrm{F}_{\text {tabel }}(3,14)$, berarti dapat disimpulkan bahwa terdapat hubungan linear secara signifikan antara variabel lingkungan kerja $\left(\mathrm{X}_{1}\right)$ dan kepemimpnan $\left(\mathrm{X}_{2}\right)$ dengan variabel kinerja pegawai (Y).

\section{Uji MultikoLinearitas}

\begin{tabular}{|c|c|c|c|}
\hline \multicolumn{4}{|c|}{ Coefficients $^{\mathrm{a}}$} \\
\hline \multirow{2}{*}{\multicolumn{2}{|c|}{ Model }} & \multicolumn{2}{|c|}{ Collinearity Statistics } \\
\hline & & Tolerance & VIF \\
\hline \multirow{2}{*}{1} & lingkungan.kerja X1 & 997 & 1,003 \\
\hline & kepemimpinan $\mathrm{X} 2$ & ,997 & 1,003 \\
\hline
\end{tabular}

Sumber : Data primer yang diolah, 2018 
Dari hasil di atas dapat diketahui nilai tolerance $(0,997)>0,10$ dan nilai Varian Inflation Factor $(1,003)<10,00$, sehingga dapat disimpulkan bahwa tidak terjadi multikolinearitas terhadap data yang di uji.

\section{Uji Heteroskedastisitas}

\begin{tabular}{|c|c|c|c|c|c|}
\hline \multicolumn{6}{|c|}{ Correlations } \\
\hline & & & \begin{tabular}{|c|} 
linkungan.kerja \\
X1
\end{tabular} & $\begin{array}{c}\text { kepemimpinan } \\
\text { X2 }\end{array}$ & $\begin{array}{l}\text { Unstandardized } \\
\text { Residual }\end{array}$ \\
\hline \multirow{9}{*}{$\begin{array}{l}\text { Spearma } \\
\text { n's rho }\end{array}$} & \multirow{3}{*}{$\begin{array}{l}\text { linkungan.kerja } \\
\text { X1 }\end{array}$} & Correlation Coefficient & 1,000 &,- 068 &,- 060 \\
\hline & & Sig. (2-tailed) & &, 542 &, 589 \\
\hline & & $\mathrm{N}$ & 83 & 83 & 83 \\
\hline & \multirow{3}{*}{$\begin{array}{l}\text { kepemimpinan } \\
\text { X2 }\end{array}$} & Correlation Coefficient &,- 068 & 1,000 &, 013 \\
\hline & & Sig. (2-tailed) &, 542 & & ,909 \\
\hline & & $\mathrm{N}$ & 83 & 83 & 83 \\
\hline & \multirow{3}{*}{$\begin{array}{l}\text { Unstandardized } \\
\text { Residual }\end{array}$} & Correlation Coefficient &,- 060 &, 013 & 1,000 \\
\hline & & Sig. (2-tailed) & ,589 & ,909 & \\
\hline & & $\mathrm{N}$ & 83 & 83 & 83 \\
\hline
\end{tabular}

Sumber : Data primer yang diolah, 2018

Dari hasil output diatas diketahui nilai signifikansi atau sig. (2-tailed) variabel lingkungan kerja $\left(X_{1}\right)$ sebesar 0,589, dan variabel kepemimpinan $\left(X_{2}\right)$ sebesar 0,909. Karena nilai kedua variabel independen (X) lebih besar dari nilai 0,05, sehingga dapat disimpulkan bahwa tidak terdapat masalah atau gejala heterokedastisitas, artinya model regresi yang dipakai untuk penelitian ini layak untuk dilakukan.

\section{Analisis Persamaan Regresi Linear Berganda}

\begin{tabular}{|c|c|c|c|c|c|c|}
\hline & 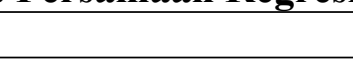 & & efficients ${ }^{\mathrm{a}}$ & & & \\
\hline & odel & $\begin{array}{r}\text { Unstan } \\
\text { Coeff }\end{array}$ & $\begin{array}{l}\text { ardized } \\
\text { cients }\end{array}$ & $\begin{array}{l}\text { Standardized } \\
\text { Coefficients }\end{array}$ & $\mathrm{t}$ & Sig. \\
\hline & & $\mathrm{B}$ & Std. Error & Beta & & \\
\hline & (Constant) & 22,403 & 5,630 & & 3,979 &, 000 \\
\hline 1 & lingkungan.kerja_X1 & ,224 & 094 & 248 & 2,379 &, 020 \\
\hline & kepemimpinan_X2 & ,273 & ,114 & ,249 & 2,388 & ,019 \\
\hline
\end{tabular}

Sumber : Data primer yang diolah, 2018

Berdasarkan tabel dapat diketahui persamaan regresi yang terbentuk adalah :

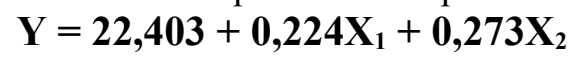

Keterangan :

$$
\begin{aligned}
& \mathrm{Y}=\text { Kinerja pegawai } \\
& \mathrm{X}_{1}=\text { Lingkungan Kerja } \\
& \mathrm{X}_{2}=\text { Kepemimpinan }
\end{aligned}
$$

Dari persamaan tersebut dapat dijelaskan bahwa :

a. Konstanta (a), Jika semua variabel bebas memiliki nilai nol (0) maka nilai variabel terikat (Kinerja pegawai) sebesar 22,403.

b. Koefisien lingkungan kerja memberikan nilai sebesar 0,224 yang berarti bahwa jika lingkungan kerja meningkat dengan asumsi variabel lain tetap maka kinerja pegawai akan mengalami peningkatan.

c. Koefisien kepemimpinan memberikan nilai sebesar 0,273 yang berarti bahwa jika kepemimpinan baik dengan asumsi variabel lain tetap maka kinerja pegawai akan mengalami peningkatan.

Uji Koefisien Determinasi $\left(\mathbf{R}^{2}\right)$

\begin{tabular}{|l|c|r|r|r|}
\hline \multicolumn{5}{|c|}{ Model Summary } \\
\hline Model & $\mathrm{R}$ & R Square & $\begin{array}{c}\text { Adjusted R } \\
\text { Square }\end{array}$ & $\begin{array}{c}\text { Std. Error of } \\
\text { the Estimate }\end{array}$ \\
\hline 1 &, $362^{\mathrm{a}}$ &, 131 &, 109 & 3,959 \\
\hline \multicolumn{5}{|c|}{$\begin{array}{l}\text { a. Predictors: (Constant), kepemimpinan_X2, } \\
\text { lingkungan.kerja_X1 }\end{array}$} \\
\hline
\end{tabular}

Sumber : Data primer yang diolah, 2018 
Hasil analisis koefisien determinasi $\mathrm{R}^{2}$ ( $\mathrm{R}$ Sequare) sebesar 0,131 menunjukkan bahwa variabel lingkungan kerja dan kepemimpinan mempengaruhi kinerja pegawai sebesar $13,1 \%$, sedangkan sisanya $86,9 \%$ dipengaruhi oleh variabel lain yang tidak diteliti dalam penelitian ini.

\section{Pengujian Hipotesis}

Uji t (Uji Hipotesis Secara Parsial)

\begin{tabular}{|c|c|c|c|c|c|c|}
\hline & & & efficients $^{a}$ & & & \\
\hline & odel & $\begin{array}{r}\text { Unstar } \\
\text { Coef }\end{array}$ & $\begin{array}{l}\text { lardized } \\
\text { cients }\end{array}$ & $\begin{array}{l}\text { Standardized } \\
\text { Coefficients }\end{array}$ & $\mathrm{t}$ & Sig. \\
\hline & & $\mathrm{B}$ & Std. Error & Beta & & \\
\hline & (Constant) & 22,403 & 5,630 & & 3,979 &, 000 \\
\hline 1 & lingkungan.kerja_X1 & 224 &, 094 & ,248 & 2,379 &, 020 \\
\hline & kepemimpinan X2 & ,273 &, 114 & 249 & 2,388 & ,019 \\
\hline
\end{tabular}

Sumber : Data primer yang diolah, 2018

Terlihat bahwa hasil pengujian hipotesis variabel kepemimpinan $\left(\mathrm{X}_{2}\right)$ menunjukkan nilai $\mathrm{t}_{\text {hitung }}$ $>\mathrm{t}$ tabel $(2,388>\mathrm{t}$ tabel 1,989$)$, maka $\mathrm{H}_{0}$ ditolak, artinya secara parsial ada pengaruh signifikan kepemimpinan terhadap kinerja pegawai. Jadi dari kasus ini dapat disimpulkan bahwa secara parsial ada pengaruh kepemimpinan terhadap kinerja pegawai pada Dinas Perdagangan dan Perindustrian Kabupaten Musi Banyuasin.

Uji F (Pengujian Hipotesis Secara Simultan)

\begin{tabular}{|c|c|c|c|c|c|c|}
\hline \multicolumn{7}{|c|}{ ANOVA $^{a}$} \\
\hline \multicolumn{2}{|c|}{ Model } & Sum of & $\mathrm{df}$ & Mean Square & $\mathrm{F}$ & Sig. \\
\hline \multirow{3}{*}{1} & Regression & 189,234 & 2 & 94,617 & 6,036 &, $004^{b}$ \\
\hline & Residual & 1253,994 & 80 & 15,675 & & \\
\hline & Total & 1443,229 & 82 & & & \\
\hline \multicolumn{7}{|c|}{ a. Dependent Variable: kinerja.pegawai_Y } \\
\hline
\end{tabular}

Sumber : Data primer yang diolah, 2018

Pengujian pengaruh variabel bebas secara bersama-sama terhadap variabel terikatnya dilakukan dengan menggunakan uji $\mathrm{F}$. Hasil perhitungan statistik menunjukkan nilai $\mathrm{F}$ hitung $=6,036$, maka diperoleh nilai $\mathrm{F}_{\text {hitung }} 6,036>$ dari $3,11 \mathrm{~F}$ tabel. Maka $\mathrm{H}_{\mathrm{o}}$ ditolak dan menerima $\mathrm{H}_{\mathrm{a}}$. Hal ini berarti bahwa hipotesis yang menyatakan bahwa secara simultan variabel lingkungan kerja dan kepemimpinan mempunyai pengaruh terhadap kinerja pegawai Pada Dinas Perdagangan dan Perindustrian Kabupaten Musi Banyuasin.

\section{Pembahasan}

\section{Pengaruh Lingkungan Kerja Terhadap Kinerja pegawai Pada Dinas Perdagangan dan Perindustrian Kabupaten Musi Banyuasin}

Hasil pengujian hipotesis ujit $\mathrm{t}\left(\mathrm{H}_{1}\right)$ telah membuktikan terdapat pengaruh antara kepemimpinan terhadap kinerja pegawai. Melalui hasil perhitungan yang telah dilakukan diperoleh nilai $t_{\text {hitung }}$ sebesar 2,379. Hasil pengujian hipotesis (uji t) Lingkungan Kerja menunjukkan nilai $t$ hitung $>\mathrm{t}$ tabel $(2,379>1,989)$, maka Ho ditolak, artinya secara parsial ada pengaruh signifikan antara Lingkungan Kerja terhadap kinerja pegawai. Jadi dari kasus ini dapat disimpulkan bahwa secara parsial Lingkungan Kerja berpengaruh terhadap kinerja pegawai pada Dinas Perdagangan dan Perindustrian Kabupaten Musi Banyuasin.

\section{Pengaruh Kepemimpinan Terhadap Kinerja Pegawai Pada Dinas Perdagangan Dan Perindustrian Kabupaten Musi Banyuasin}

Hasil pengujian hipotesis $\left(\mathrm{H}_{2}\right)$ telah membuktikan terdapat pengaruh antara kepemimpinan terhadap kinerja pegawai. Melalui hasil perhitungan yang telah dilakukan didapat nilai $t$ hitung sebesar 2,388 . Hasil nilai $\mathrm{t}_{\text {hitung }}>\mathrm{t}$ tabel $(2,388>1,989)$, maka $\mathrm{H}_{0}$ ditolak, artinya secara parsial ada pengaruh signifikan antara kepemimpinan dan kinerja pegawai. Jadi dari kasus ini dapat disimpulkan bahwa 
secara parsial kepemimpinan ada pengaruh terhadap kinerja pegawai pada Dinas Perdagangan dan Perindustrian Kabupaten Musi Banyuasin.

\section{Pengaruh Lingkungan Kerja Dan Kepemimpinan Terhadap Kinerja Pegawai Pada Dinas Perdagangan Dan Perindustrian Kabupaten Musi Banyuasin}

Hasil penelitian dari pengujian pengaruh variabel bebas secara bersama-sama terhadap variabel terikatnya dilakukan dengan menggunakan uji F. Hasil perhitungan statistik menunjukkan nilai $\mathrm{F}_{\text {hitung }}=6,036$, maka diperoleh nilai $\mathrm{F}_{\text {hitung }} 6,036>$ dari $\mathrm{F}_{\text {tabel }} 3,11$. Maka $\mathrm{H}_{\mathrm{o}}$ ditolak dan menerima $\mathrm{H}_{\mathrm{a}}$. Hal ini berarti bahwa hipotesis yang menyatakan bahwa secara simultan variable ada pengaruh lingkungan kerja dan kepemimpinan terhadap kinerja pegawai pada Dinas Perdagangan Dan Perindustrian Kabupaten Musi Banyuasin. Besarnya pengaruh tersebut termasuk kecil, karena selain lingkungan kerja dan kepemimpinan masih banyak faktor lain yang juga mempengaruhi kinerja pegawai. Agar kita dapat mencapai kinerja pegawai yang maksimal, maka kita harus memahami faktor-faktor yang mempengaruhi kinerja pegawai tersebut. Kinerja pegawai akan semakin meningkat ketika faktor-faktor yang mempengaruhi berpengaruh secara selaras dan positif.

\section{Implementasi Hasil Penelitian}

Berdasarkan hasil penelitian dari pengujian pengaruh variabel bebas secara simultan terhadap variabel terikatnya dilakukan dengan menggunakan uji F. Hasil perhitungan statistik menunjukkan nilai $\mathrm{F}_{\text {hitung }}=6,036$, maka diperoleh nilai $\mathrm{F}_{\text {hitung }} 6,036>$ dari $\mathrm{F}_{\text {tabel }} 3,11 . \mathrm{Maka}_{\mathrm{o}}$ ditolak dan menerima $\mathrm{H}_{\mathrm{a}}$. Hal ini berarti bahwa hipotesis yang menyatakan bahwa secara simultan variable ada pengaruh lingkungan kerja dan kepemimpinan terhadap kinerja pegawai pada Dinas Perdagangan Dan Perindustrian Kabupaten Musi Banyuasin.

Hasil penelitian ini mendukung penelitian yang dilakukan oleh Tri Widodo (2010). Dengan judul penelitian 'Pengaruh Lingkungan Kerja, Budaya Organisasi, Kepemimpinan Terhadap Kinerja (Studi pada Pegawai Kecamatan Sidorejo Kota Salatiga)'. Dari hasi penelitian di ketahui bahwa hasil perhitungan uji $\mathrm{F}$ ternyata $\mathrm{F}_{\text {hitung }} 16,594$ dan $\mathrm{F}_{\text {tabel }}(0,05 ; 3,56)=4,16$, oleh karena itu, hasil analisis data menunjukkan bahwa $\mathrm{F}_{\text {hitung }}>\mathrm{F}_{\text {tabel }}(0,05 ; 3,56)$. Kesimpulan yang dapat diambil adalah $\mathrm{H} 0$ ditolak dan Ha diterima, sehingga hipotesis yang menyatakan bahwa "ada pengaruh yang signifikan antara variabel lingkungan kerja, budaya organisasi, dan kepemimpinan terhadap kinerja pegawai Kecamatan Sidorejo Kota Salatiga, diterima kebenaranya.

\section{Kesimpulan}

a. Berdasarkan hasil analisis persamaan regresi linear berganda dapat diketahui persamaan regresi

$22,403+0,224 \mathrm{X}_{1}+0,273 \mathrm{X}_{2}$ yang dapat dijelaskan bahwa :

1) Konstanta (a), Jika semua variabel bebas memiliki nilai nol (0) maka nilai variabel terikat (Kinerja pegawai) sebesar 22,403.

2) Koefisien lingkungan kerja memberikan nilai sebesar 0,224 yang berarti bahwa jika lingkungan kerja baik dan meningkat dengan asumsi variabel lain tetap maka kinerja pegawai akan mengalami peningkatan dan pegawai akan merasa bersemangat dalam bekerja.

3) Koefisien kepemimpinan sebesar 0,273 yang berarti bahwa jika kepemimpinan baik dengan asumsi variabel lain tetap maka kinerja pegawai akan mengalami peningkatan dan pegawai dalam bekerja akan merasa nyaman.

b. Hasil perhitungan nilai variabel kinerja pegawai $(r)$ sebesar 0,362 . sedangkan nilai $\mathrm{r}^{2}$ ( $\mathrm{r}$ sequare) sebesar 0,131 menunjukan bahwa variabel kepemimpinan dan lingkungan kerja mempengaruhi kinerja pegawai sebesar $13,1 \%$, sedangkan sisanya $86,9 \%$ dipengaruhi oleh variabel lain yang tidak diteliti dalam penelitian ini.

c. Berdasarkan hasil pengujian hipotesis dapat di simpulkan bahwa :

1) Hasil pengujian hipotesis menggunakan uji $t$ dapat disimpulkan bahwa secara parsial lingkungan kerja pegawai berpengaruh terhadap kinerja pegawai pada Dinas Perdagangan dan Perindustrian Kabupaten Musi Banyuasin

2) Hasil pengujian hipotesis menggunakan uji $t$ dapat disimpulkan bahwa secara parsial kepemimpinan berpengaruh terhadap kinerja pegawai pada Dinas Perdagangan dan Perindustrian Kabupaten Musi Banyuasin.

3) Hasil pengujian hipotesis menggunakan uji f, dapat disimpulan bahwa secara simultan variabel lingkungan kerja dan kepemimpinan mempunyai pengaruh terhadap kinerja pegawai pada Dinas Perdagangan dan Perindustrian Kabupaten Musi Banyuasin. 


\section{DAFTAR PUSTAKA}

Bandur, Agustinus. 2013. Penelitian Kuantitatif, Desain dan Analisis Data Dengan SPSS. Jakarta : CV. Budi Utama.

Bangun, Wilson. 2012. Manajemen Sumber Daya Manusian. Jakarta. Erlangga.

Dachlan, Usman. 2014. Structural Equation Modeling. Semarang : Lentera Ilmu.

Dessler, Gary, 2010. Manajemen Sumber Daya Manusia. Edisi Kesepuluh. Jilid Dua. Jakarta : PT Indeks

Griffin W. Rizki. 2009. Pengantar Manajemen. Jakarta. : PT. Gramedia Utama.

Handoko, Hani. 2011. Manjemen personalia. Yogyakarta : BFEE.

Hasibuan, Malayu SP. 2010. Manajemen Sumber Daya Manusia. Jakarta : PT. Bumi Aksara.

Hendri, Edduar. 2012. Pengaruh Lingkungan Kerja Fisik dan Non Fisik Terhadap Kepuasan Kerja Karyawan Pada PT Asuransi Wahana Tata Cabang Palembang. Jurnal Media Wahana. Vol. 9 No. 3. Diunduh dari httpced.petra.ac.idindex. Tanggal 26 September 2018.

Mangkunegara, Anwar P. 2010. Evaluasi Kinerja Sumber Daya Manusia. Bandung : PT. Refika Aditama.

Rivai. Veitthzal. 2012. Manajemen Sumbe Daya Manusia Untuk Perusahaan. Bandung : PT. Remaja Rosada Karya.

Robbins, Stephen, P. 2010. Prinsip-Prinsip Perilaku Organisasi. Jakarta : Erlangga.

Sedarmayanti. 2011. Tata Kerja dan Produktivitas Kerja. Bandung: Mandar Maju.

Siagian, Sondang. P. 2010. Kiat Meningkatkan Produktivitas Kerja. Jakarta : PT Rineka Cipta.

Sofyan, Diana Khairani. 2013. Pengaruh Lingkungan Kerja Terhadap Kinerja BAPPEDA. Jurnal Malikussaleh Industrial Engineering. Vol. 2 No. 1. Diunduh dari httpeprints.undip.ac.id149701 Tanggal 26 September 2018.

Sugiyono. 2011. Metode Penelitian. Bandung : CV. Alfabeta.

Sunyoto. 2013. Metode dan Instrument Penelitian. Yogyakarta : CAPS (Center For Academic Publishing Service).

Terry, George R. 2011. Manajemen Sumber Daya Manusia. Jakarta: PT. Bumi Aksara

Thoha, Miftah. 2011. Perilaku organisasi. Jakarta. Edisi 1. Cetakan ke 23 : Rajawali Pers.

Wibowo. 2014. Manajemen Kinerja. Jakarta : PT. Rajagrafindo Persada.

Wijaya, Hendry. 2017. Pengaruh Lingkungan Kerja Terhadap Kinerja Pegawai Pada Instansi Pemerintah Daerah Kabupaten Musi Banyuasin. Jurnal. Volume 2 Nomor 1 Edisi Februari 2019. Di unduh dari http://ejournal.uigm.ac.id/index.php/EG/article/download/213/217 Tanggal 26 September 2018 